\title{
Molecular mechanisms of gastric epithelial cell adhesion and injection of CagA by Helicobacter pylori
}

\author{
Steffen Backert ${ }^{1 *+}$, Marguerite Clyne ${ }^{2+}$ and Nicole Tegtmeyer ${ }^{1+}$
}

\begin{abstract}
Helicobacter pylori is a highly successful pathogen uniquely adapted to colonize humans. Gastric infections with this bacterium can induce pathology ranging from chronic gastritis and peptic ulcers to gastric cancer. More virulent $H$. pylori isolates harbour numerous well-known adhesins (BabA/B, SabA, AlpA/B, OipA and HopZ) and the cag (cytotoxin-associated genes) pathogenicity island encoding a type IV secretion system (T4SS). The adhesins establish tight bacterial contact with host target cells and the T4SS represents a needle-like pilus device for the delivery of effector proteins into host target cells such as CagA. BabA and SabA bind to blood group antigen and sialylated proteins respectively, and a series of T4SS components including Cagl, CagL, CagY and CagA have been shown to target the integrin $\beta_{1}$ receptor followed by injection of CagA across the host cell membrane. The interaction of CagA with membrane-anchored phosphatidylserine may also play a role in the delivery process. While substantial progress has been made in our current understanding of many of the above factors, the host cell receptors for OipA, HopZ and AlpA/B during infection are still unknown. Here we review the recent progress in characterizing the interactions of the various adhesins and structural T4SS proteins with host cell factors. The contribution of these interactions to $\mathrm{H}$. pylori colonization and pathogenesis is discussed.
\end{abstract}

Keywords: Helicobacter pylori, adherence, adhesin, integrin, receptor, signalling, type IV secretion

\section{Introduction}

H. pylori colonises the stomach of about half of the human world population, which is associated with chronic, often asymptomatic gastritis in all infected individuals. Depending on various criteria, more severe gastric diseases including peptic ulcer disease can occur in up to $10-15 \%$ of infected persons [1-3]. H. pylori infections are commonly diagnosed with a strong inflammatory response, but the bacteria evolved numerous mechanisms during evolution to avoid recognition and clearance by the host defence machineries, and if not treated with antibiotics, they can persist for life. $H$. pylori-induced gastritis is the strongest singular risk factor for developing cancers of the stomach; however, only a small proportion of infected individuals develop

\footnotetext{
* Correspondence: steffen.backert@ucd.ie

† Contributed equally

'University College Dublin, School of Biomolecular and Biomedical Sciences,

Science Center West, Belfield Campus, Dublin-4, Ireland
}

Full list of author information is available at the end of the article malignancy such as mucosa-associated lymphoid tissue (MALT) lymphoma and even gastric adenocarcinoma [1-3]. Gastric adenocarcinoma constitutes the second leading cause of cancer-associated death worldwide, and about 700,000 people die from this malignancy annually [3]. The clinical outcome of infection with $H$. pylori is dependent on a very complex scenario of host-pathogen crosstalk. Disease progression is determined by various factors including the genetic predisposition of the host, the bacterial genotype and environmental parameters [1-3]. The cellular and molecular mechanisms developed by $H$. pylori to undermine host defence strategies have been under intense investigation worldwide.

Clinical $H$. pylori strains are highly diverse both in their genetic information and potential to induce pathogenicity. Myriads of bacterial factors have been reported to influence the pathogenesis of $H$. pylori infections. There are two classical virulence determinants expressed by $H$. pylori, the CagA protein encoded by the cytotoxinassociated genes pathogenicity island (cagPAI) and the 
vacuolating cytotoxin (VacA). Secreted VacA can trigger various responses including pore formation in the host cell membrane, modification of endo-lysosomal trafficking, cellular vacuolation, immune cell inhibition and apoptosis. VacA's activities are highlighted in several review articles [1-4] and will not be discussed here. In the mid nineties, the cagPAI was entirely sequenced from various $H$. pylori strains and found to represent a $40-\mathrm{kb}$ DNA insertion element in the chromosome, which is flanked by 31-bp direct repeats and carrying up to 32 genes $[5,6]$. Large scientific interest concentrates on the CagA protein which is present in more virulent isolates, but is typically absent in less virulent $H$. pylori strains. Thus, CagA serves as a virulence marker for the cagPAI $[7,8]$. Work in the last ten years has shown that the cagPAI encodes type-IV secretion system (T4SS) which injects CagA into target cells where it interferes with multiple host cell signaling cascades $[9,10]$. Other welldescribed pathogenicity-associated mechanisms include flagella-driven bacterial motility, urease-mediated neutralization of $\mathrm{pH}$, HtrA-mediated cleavage of E-cadherin, modification of host cell cholesterol, shedding of outermembrane vesicles and peptidoglycan-dependent immune responses [1-3,11-13]. In addition, $H$. pylori carries several classical surface adhesins permitting tight adherence of the bacteria to gastric epithelial cells. Here we review the various molecular adhesion strategies of $H$. pylori to gastric epithelial target cells which facilitate bacterial binding. We also discuss the structure and function of the T4SS, and how it makes contact with host cell surface factors to inject the CagA effector protein.

\section{Role of the classical $\boldsymbol{H}$. pylori adhesins}

Intensive research in recent years has demonstrated that $H$. pylori encodes a broad set of various adhesion factors, for some of which the corresponding host cell receptor(s) have been identified (Table 1). The $H$. pylori genomes from various strains contain more than 30 genes which encode outer membrane proteins (OMPs) that have been divided into Hop (Helicobacter outer membrane porins) and Hor (hop-related) subgroups. The Hop family of proteins includes several well described adhesins of $H$. pylori such as BabA, SabA, AlpA/B, HopZ and OipA. However, among clinical strains of $H$. pylori considerable diversity in the expression of OMPs exists. This is thought to reflect a selective pressure for bacterial adhesion which may differ both across and within infected individuals over time. It has been shown that some of the classical adhesion molecules discussed below act in conjunction with factors from the cagPAI in order to highjack several host cell processes including altered transcription, cytoskeletal rearrangements, opening of cell-to-cell junctions, onset of inflammation and others as summarized in a simplified model (Figure 1A).

Table 1 Characteristics of cagPAl-independent and cagPAl-dependent host cell adhesion factors ${ }^{\mathrm{a}}$

\begin{tabular}{|c|c|c|c|c|c|}
\hline $\begin{array}{l}\text { Bacterial } \\
\text { factor }\end{array}$ & Reported host receptor & Cell systems used & $\begin{array}{l}\text { H. pylori strains } \\
\text { used }\end{array}$ & Applied methods & References \\
\hline \multirow[t]{2}{*}{ BabA } & $\begin{array}{l}\text { Fucosylated blood group } \\
\text { antigens Leb, and } \mathrm{H} 1\end{array}$ & $\begin{array}{l}\text { Human gastric tissue } \\
\text { sections }\end{array}$ & $\begin{array}{l}\text { P466, CCUG17875, } \\
\text { A5, M019, } 26695\end{array}$ & $\begin{array}{l}\text { RIA, Receptor displacement asssay, Scatchard } \\
\text { analysis, }\end{array}$ & [14] \\
\hline & $\begin{array}{l}\text { Leb, H1, A, ALeb, and } \\
\text { BLeb }\end{array}$ & - & $\begin{array}{l}\text { P466, CCUG17875, } \\
\text { J99 }\end{array}$ & $\begin{array}{l}\text { Overlay binding studies with radiolabelled } \\
\text { glycoconjugates }\end{array}$ & {$[15]$} \\
\hline BabB & Unknown & - & - & - & - \\
\hline \multirow[t]{2}{*}{$\overline{S a b A}$} & $\begin{array}{l}\text { Sialylated dimeric Lewis } \mathrm{x}, \\
\text { Sialyl Lea antigen }\end{array}$ & $\begin{array}{l}\text { Human and monkey } \\
\text { gastric tissue sections }\end{array}$ & $\begin{array}{l}\text { CCUG17875, J99, } \\
\text { 26695, SM165, WU12 }\end{array}$ & RIA and Scatchard analysis & {$[26]$} \\
\hline & Laminin & - & J99 & Glycoconjugate array binding studies & [30] \\
\hline OipA & Unknown & AGS, KATO-III & $\mathrm{B} 128, \mathrm{G} 27$ & Bacterial adherence assays & {$[37]$} \\
\hline AlpA/B & Laminin & - & 26695, SS1 & $\begin{array}{l}\text { Flow cytometry, Biacore binding studies, } \\
\text { surface adherence assay }\end{array}$ & [33] \\
\hline HopZ & Unknown & AGS & $\begin{array}{l}\text { ATCC43504, 342, } \\
326 / 01\end{array}$ & AGS cell adhesion assays & {$[39]$} \\
\hline \multirow[t]{2}{*}{ CagA } & $\beta 1$ integrin & GE11 vs. GE11ß1 & $\mathrm{P} 12$ & $\begin{array}{l}\text { Y2H, PD with magnetic beads, FACS, Biacore } \\
\text { binding studies }\end{array}$ & [82] \\
\hline & Phosphatidylserine & AGS & NCTC11637 & Binding studies, CF, AB blocking, IF & [83] \\
\hline Cagl & $\beta 1$ integrin & - & - & Y2H, PD with magnetic beads, FACS & [82] \\
\hline CagL & $\beta 1$ integrin & $\begin{array}{l}\text { AGS, GD25 vs. GD25 } 1 \text {, } \\
\text { HeLa, mouse fibroblasts }\end{array}$ & P1, P12 & $\begin{array}{l}\text { Biacore binding studies, Peptide competition, } \\
\text { cell adhesion assays, AB blocking, CF }\end{array}$ & {$[61,81]$} \\
\hline$\overline{\text { CagY }}$ & $\beta 1$ integrin & GE11 vs. GE11ß1 & $\mathrm{P} 12$ & $\mathrm{Y} 2 \mathrm{H}$, PD with magnetic beads, FACS & {$[82]$} \\
\hline
\end{tabular}

a Abbreviations: AB (antibody); CF (cellular fractionation); FACS (Fluorescence-activated cell sorting); IF (co-localization by immunofluorescence); PD (pull-down experiments); RIA (Radioimmuno assay); $\mathrm{Y} 2 \mathrm{H}$ (yeast two hybrid screen). 


\section{BabA}

The OMP member BabA was the first H. pylori adhesin discovered. BabA mediates binding of the bacteria to Lewis B antigens, Leb [14] and related terminal fucose residues found on blood group $\mathrm{O}$ ( $\mathrm{H}$ antigen), $\mathrm{A}$ and $\mathrm{B}$ antigens [15] that are expressed on the gastric mucosa. Multiple chromosomal loci and alleles for BabA have been reported to exist and Leb binding activity was shown to be facilitated by the BabA2 allele [14]. However, more recent work suggests that BabA1 alleles occur only very rarely and are difficult to detect [16] Substantial amino acid polymorphisms exist among BabA proteins expressed by different strains [17]. Diversity also appears with respect to the binding of strains to Leb and BabA expression, and binding affinity for $\mathrm{A}, \mathrm{B}$ and $\mathrm{O}$ antigens correlates with blood group antigen expression of the host $[15,18]$. A closely related gene $b a b B$, encodes for a translation product which has significant $\mathrm{N}$ - and C-terminal similarity to BabA. BabA and babB are nearly identical in their 5' and 3 ' regions but there is sequence divergence in their mid region [19] indicating that the central variable regions likely encode unique functions. Many Leb non-binding strains express silent $b a b A$ gene sequences which may become activated by recombination into the $b a b B$ locus forming chimeric $b a b B / A$ genes [20]. BabA expression in vivo, however, appears to be highly dynamic. Experimental infection of Rhesus Macaques, mice and Mongolian gerbils resulted in loss of BabA expression and Leb binding $[21,22]$. Post-infection strains isolated from gerbils contained a BabA2 protein that was modified by six amino acids from the strain used for inoculation. Complementation experiments confirmed these six amino acid residues are critical for binding to fucosylated blood group antigens [22]. In a recent study, experimental infection of Mongolian gerbils resulted in complete absence of expression of BabA at six months post-infection. Loss of BabA expression was attributable to nucleotide changes within the $b a b A$ gene that resulted in a truncated BabA translation product [23]. BabA-mediated adherence of $H$. pylori to Leb on the surface of epithelial cells has been shown in vitro, using Leb transfected MDCK cells, and in vivo, using infection of Mongolian gerbils, to augment cagPAI-dependent $H$. pylori pathogenicity by triggering the production of proinflammatory cytokines and precancer-related factors [24] (Figure 1A). Thus, the expression of the BabA adhesin seems tightly connected to the onset of T4SS-
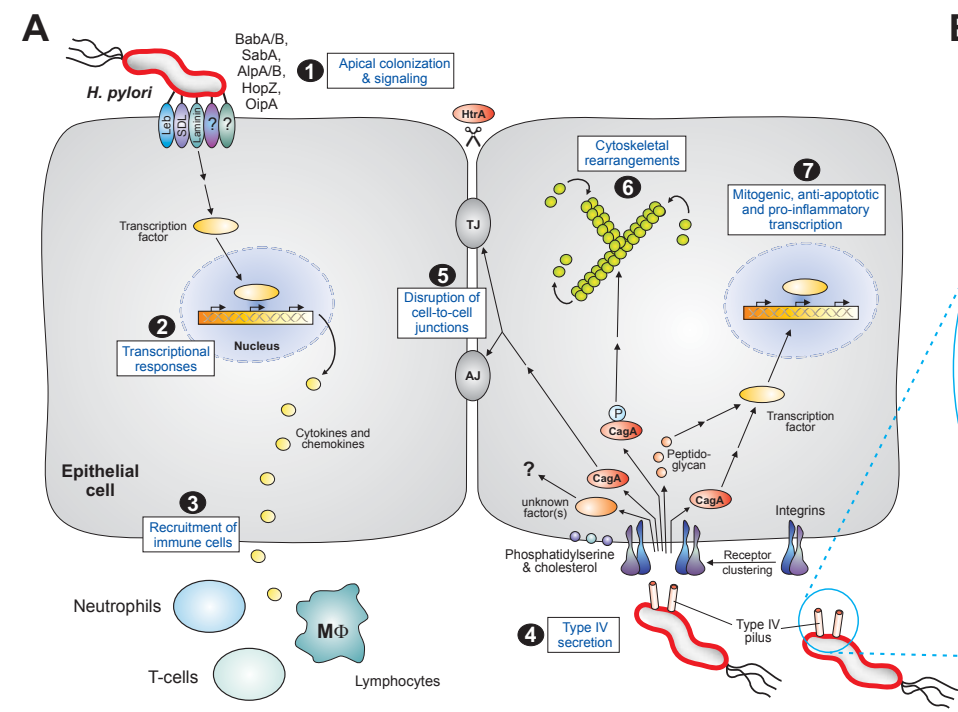

B

Figure $1 \mathrm{H}$. pylori interactions with epithelial cells highlighting the roles of adhesins and the type-IV secretion system (T4SS) encoded by cagPAI. (A) (1) H. pylori adhesins mediate apical binding to known and unknown receptors on gastric epithelium and probably also direct signal transduction as indicated. (2) Upregulation of transcription factors such as NF- $\kappa$ B leads to production of pro-inflammatory cytokines and chemokines. (3) Secretion of mediators at basolateral surfaces attracts immune cells to the site of infection. (4) Upon host cell contact, H. pylori assembles T4SS pili at their surface enabling delivery of molecules, CagA and peptidoglycan, from bacterial cytoplasm into host cells. cagPAl proteins (CagA, Cagl, CagL and CagY) interact with integrin receptors. Interactions with phosphatidylserine (PS) and cholesterol in lipid rafts are also involved in T4SS processes. T4SS and CagA are involved in numerous cellular effects including disruption of cell-to-cell junctions (5), cytoskeletal rearrangements (6) and nuclear signalling (7). (B) Two models for the assembled T4SS machinery in H. pylori are proposed. Model-1 assumes VirB111 proteins, the coupling factor VirD4 and accessory factors such as CagF (a proposed chaperone of CagA) assemble in a similar fashion to that proposed for A. tumefaciens T4SS [10]. Model-2 assumes that the T4SS requires the same VirB/D proteins as model-1 with two major differences. The T4SS pilus surface is covered with CagY (VirB10) molecules and VirB5 is excluded [50]. H. pylori VirB10 is a very large protein ( 250 kDa) carrying two transmembrane domains to form a hairpin-loop structure in the pilus as depicted [64]. Immunogold labelling of the loop region in CagY indicated that this is exposed to the extracellular space and is transported to the pilus surface by an unknown mechanism [64]. Abbreviations: AJ (adherens junction); HtrA (High temperature requirement A protease); Leb (Lewis B antigens); MФ (macrophage); NTP (nucleotide triphosphate); NDP (nucleotide diphosphate); P (phosphate group); SDL (sialyl-dimeric-Lewis $\times$ glycosphingolipid); TJ (tight junction). 
related host cell responses in vivo. The presence of $b a b A$ is associated with cagA and $v a c A$ s1 alleles, and strains that possess all three of these genes incur the highest risk of gastric cancer development [25].

\section{SabA}

Expression of sialyl-dimeric-Lewis $\times$ glycosphingolipid is upregulated upon infection with $H$. pylori and inflammation. This molecule also acts as a receptor for the pathogen and binding is mediated through the bacterial OMP member, SabA [26]. No binding to gangliosides was obtained with a SabA-negative mutant strain using a thin layer chromatography overlay assay [27]. Infection of the gastric epithelial cancer cell line MKN45 with $H$. pylori upregulated expression of the gene encoding $\beta 3$ GlcNAc T5, a GlcNAc transferase essential for the biosynthesis of Lewis antigens. Overexpression of this gene in both the MKN45 and AGS gastric adenocarcinoma cell lines lead to expression of the SabA ligand, sialyl Lex, suggesting that $H$. pylori can modulate receptor expression [28]. SabA has been identified as a haemagglutinin that binds to sialylated structures found on the surface of red blood cells and there is a good correlation among strains between sialic acid dependent haemagglutination and sialyl Lex binding [29]. Like observations with BabA, a high level of polymorphism was reported in sialyl binding properties among clinical $H$. pylori isolates, which suggests that SabA adapts to its host depending on the mucosal sialylation pattern of the infected individual [29]. SabA has also been shown to mediate binding of $H$. pylori to sialylated moieties on the extracellular matrix protein laminin [30].

\section{AlpA/B}

Two strongly homologous genes termed $\operatorname{alp} A$ and $a l p B$ were also characterized and shown to encode for integral OMPs. Adhesion experiments indicated that they are also involved in adherence of $H$. pylori to human gastric tissue biopsies [31]. OMP expression profiling of 200 strains from Germany revealed that virtually all clinical isolates produced the AlpA and AlpB proteins in contrast to many other OMPs that were produced at very variable rates [32]. Recently both AlpA and AlpB proteins have been shown to bind to mouse laminin in vitro and plasmid-borne alpA conferred laminin-binding ability on E. coli [33]. No other binding partners or receptors for AlpA and AlpB have yet been identified. The $\operatorname{alpA/B}$ locus has also been shown to influence host cell signaling and cytokine production upon infection. Deletion of $\operatorname{alp} A / B$ genes reduced IL-8 induction during infection with East Asian but not with Western $H$. pylori strains [34]. The $\operatorname{alp} A / B$ mutants poorly colonized the stomachs of C57BL/6 mice and were associated with lower mucosal levels of induced $\mathrm{KC}$ (the mouse name for human IL-8) and IL-6 [34]. In contrast to these results, in another recent study $\operatorname{alp} A$ and $\operatorname{alp} B$ gene mutants of $H$. pylori SS1 induced more severe inflammation than the parental strain in infected gerbils [33].

\section{OipA}

OipA (outer inflammatory protein A), encoded by the hopH gene, was initially identified as a surface protein that promoted IL- 8 production in a T4SS-independent fashion [35]. OipA expression by $H$. pylori was shown to be significantly associated with the presence of duodenal ulcers and gastric cancer, high $H$. pylori density, and severe neutrophil infiltration [36]. Later studies identified that hopH knockout mutant strains adhered significantly less to gastric cancer cell lines, AGS and Kato-III, than wild-type strains, and complementation of the hopH gene restored the adherence properties of the hopH mutant [37]. The presence of oipA has also been shown to clearly enhance production of IL-8 in vitro but only in the presence of the cagPAI [32]. Further insights came from infection studies for up to 52 weeks in the Mongolian gerbil model system. All infected gerbils developed gastritis; however, inflammation was significantly attenuated in animals infected with the $\triangle c a g A$, but not the single $\Delta v a c A$ or $\triangle$ oip $A$ strains [38]. However, inactivation of oip $A$ decreased nuclear localization of $\beta$-catenin, a factor involved in transcriptional up-regulation of genes implicated in carcinogenesis, and reduced the incidence of cancer in the gerbils. OipA expression was detected significantly more frequently among $H$. pylori strains isolated from human subjects with gastric cancer precursor lesions versus persons with gastritis alone [38]. The host receptor for OipA, however, remains unknown.

\section{Hopz}

The hopZ gene encodes a protein which was shown by immunofluoresence to be located on the surface of the bacteria. A knockout mutant strain showed significantly reduced binding to the AGS cell line, compared to the corresponding wild-type strain [39]. Lack of production of HopZ did not affect the ability of the bacterium to colonize the stomachs of guinea pigs [40]. However, a role for HopZ in colonization in vivo has recently been proposed as deletion of hop $Z$ reduced the ability of $H$. pylori to survive in a germ-free transgenic mouse model of chronic atrophic gastritis [41]. In addition, one of the few differences identified in $H$. pylori strains isolated from infected volunteers, was an OFF/ON switch in the phase-variable hop $Z$ gene suggesting strong in vivo selection for HopZ during colonization [42]. Similar to OipA, the host receptor for HopZ has not yet been identified and will be a major challenging aim for future research. 


\section{Role of the cagPAI in cell adhesion and T4SS function \\ Composition of the H. pylori T4SS apparatus}

The T4SS in the cagPAI belongs to a large group of transmembrane transporters that are ancestrally related to plasmid DNA conjugation systems of Gram-negative bacteria and have been found in many pathogenic and non-pathogenic organisms $[9,43,44]$. Although evolutionary conserved, T4SSs are functionally heterogenous in respect to both the delivered substrate (DNA-protein complexes or proteins) and the involved recipients. Recipients can be either bacteria of the different or same species, or species from other kingdoms including plants, fungi and mammalian cells. Besides H. pylori, T4SSs have also been found in Agrobacterium, Legionella, Bartonella, Bordetella and other pathogens, and typically consist of a distinct set of VirB/D proteins. The latter include the VirB1-VirB11 components and the socalled coupling factor, the NTPase VirD4. The agrobacterial T-DNA system is the prototype of a T4SS transporter and its VirB proteins have been classified into three groups: (i) the putative core or channel subunits (VirB6-10), (ii) the energetic components (the NTPases VirB4 and VirB11) and (iii) the pilus-associated proteins (VirB2, and possibly VirB3 and VirB5). VirB1 is a proposed transglycosylase for limited lysis of the murein layer at the T4SS assembly site in the membrane $[45,46]$. In case of the H. pylori T4SS, all orthologs of the 11 VirB proteins and VirD4 as well as some accessory factors have been identified to be encoded by the cagPAI $[10,47,48]$. Mutagenesis of all individual cagPAI genes revealed at least 14 essential and two accessory components while some other genes are not required for injecting CagA $[9,49,50]$. The function of many accessory T4SS factors is not yet clear, however, the role of CagF and CagD was recently elucidated. CagD appears to serve as a potential multifunctional component of the T4SS which may be involved in CagA injection at the inner membrane and may localize outside the bacteria to promote other responses in host cells [51]. In addition, CagF is a chaperone-like protein for CagA that binds close to the carboxy-terminal secretion motif of the effector protein, which is important for its translocation by the T4SS [52,53]. Further studies using yeast two-hybrid technology, fractionation and immunoprecipitation approaches identified selective interactions of numerous cagPAI proteins which are likely to have an important role in early T4SS assembly steps [50,54].

\section{Crystal structure of the T4SS core complex and several cagPAl proteins}

A major contribution to our current knowledge about T4SS nanomachineries in bacteria came from resolution of crystal structures of the T4SS-core from plasmid
pKM101 [45,55]. Three proteins (VirB7, VirB9 and VirB10) assemble into a $\sim 1$ megadalton structure spanning the inner and outer membranes. This core structure consists of 14 copies of each of the proteins and forms two layers, inserting in the inner and outer membrane, respectively [45]. The crystal structure of a $\sim 0.6$ megadalton outer-membrane complex containing the entire $O$ layer was solved at higher resolution [55]. Comparison of the structures points to conformational changes regulating T4SS channel opening and closing, which could be involved in the transport of effector molecules $[45,55]$. In addition to these major findings, the crystal structures of four individual structural cagPAI proteins have been reported. The structure of VirB11 revealed a hexameric ring complexed with the regulatory protein HP1451, which functions as a gating factor in the inner membrane, proposed to cycle through closed and open conformations as triggered by ATP-binding and ATP-hydrolysis, respectively [56-58]. The crystal structures of CagS, a 23-kDa protein coded by a well-conserved cagPAI gene whose exact function remains elusive, and CagZ, a 23-kDa protein involved in the translocation of CagA, have also been solved [59,60]. Moreover, the structural characterization of CagD indicated that it exists as a covalent dimer in which each monomer folds as a single domain that is composed of three $\alpha$-helices and five $\beta$-strands [51]. In addition, the structure of CagL has been modelled based on the crystal structure available from TraC of pKM101, another VirB5 ortholog [47]. CagL seems to form a three $\alpha$-helical bundle structure with an exposed domain, which is in agreement with its published circular dichroism (CD) spectrum that revealed $\sim 65 \%$ helical sequences [61].

Finally, the $2.2-\AA$ crystal structure of a carboxyterminal part of CagA in complex with one of its cellular targets, the human kinase Par1b/MARK2, was recently solved [62]. The CagA peptide interacted with the kinase as an extended coil. The visible 14amino acid peptide sequence spanned the "FPLKRHDKVDDLSK" motif, a sequence occurring twice in the crystallized CagA construct. This CagA peptide was named MKI (for MARK2 kinase inhibitor) in analogy to PKI, a well-described peptide inhibitor of protein kinase A. Interestingly, the manner in which the MKI sequence of CagA binds in the substrate-binding cleft of Par1b/MARK2 is reminiscent of the manner by which PKI binds to and inhibits PKA. Taken together, the first CagA substructure revealed that it mimics host cell kinase substrates, using a short MKI peptide to attach to the substrate binding site of Par1b/MARK2 [62]. However, injected CagA also interacts with many other host cell proteins, involved in multiple signalling cascades (Figure 1A), which are discussed elsewhere $[7,8]$. 


\section{Structure of the T4SS apparatus in live $H$. pylori}

Electron microcopy of infecting $H$. pylori has demonstrated that assembly of the T4SS is induced after host cell contact and represents a needle-like structure extending from the bacterial outer membrane, also called T4SS-pili $[61,63,64]$. These pili are proposed to consist of $\mathrm{CagC}$, which was identified as the major VirB2 pilin subunit ortholog [65], however, direct labeling of the pili with $\alpha$-VirB2 antibodies was not yet demonstrated. Studies using antibody-labelling with immunogold have shown that the bacterial protrusions are decorated by VirB10 (CagY) [64] and VirB5 (CagL) [61]. CagY proteins are about 250-kDa in size and can differ enormously in size between strains and changes size during colonization of a given host. In-frame deletions or duplications rearrangements in VirB10 can result in reduced host antibody recognition which may allow immune evasion [66]. The T4SS-needle base can be stained with antibodies against VirB7 (CagT) and VirB9 (CagW) proteins $[63,64]$. In addition, immunogold-staining indicated the presence of CagA at the tip of the appendages, providing the first direct evidence that CagA may be indeed delivered through the pilus, an observation not yet reported for T4SS substrates in other bacteria [61]. However, transport of CagA through the T4SS is proposed to occur by an energy-dependent mechanism stimulated by the concerted action of NTPases VirB4, VirB11 and VirD4 [46,56,67].

There are two T4SS-pilus assembly models proposed for $H$. pylori. As outlined above, all orthologs of the 11 VirB proteins and VirD4 have been identified to be encoded in the cagPAI as well as some accessory proteins [10], leading to a T4SS model similar to that of the agrobacterial T4SS (Figure 1B, left). In line with these conclusions, immunogold-labelling studies indicated that the tips of the T4SS pilus are decorated with CagL/VirB5 [61], which exhibited a similar distribution of VirB5 orthologs on the T4SS pilus in Agrobacterium [68]. In a second model (Figure 1B, right), it has been proposed that the appendages in $H$. pylori are covered locally or completely by CagY [64] and the T4SS includes all VirB components, except VirB5 [50]. Remarkably, CagY is a very large protein containing two transmembrane segments with the mid region (also called the repeat domain) exposed to the extracellular side like a hairpin-like structure [64]. As described above, VirB10 forms the inner core in a common T4SS model $[45,55]$, but $H$. pylori CagY/VirB10 clearly differs from their counterparts in other T4SSs [69]. Thus, further studies are necessary to investigate if the T4SS pilus in H. pylori is more similar to that in Agrobacterium (mainly composed of VirB2 and VirB5 subunits) or if it is made-up of CagY as major pilus protein, or if it is a mix of both (Figure 1B).

\section{The function of the T4SS depends on the used cell system}

Although $H$. pylori is a stomach-specific pathogen in humans, infection studies in vitro have shown that CagA can be injected into many different cell types. A summary of human cell types with reported susceptibility for the uptake of T4SS-delivered CagA in vitro is shown in Table 2. The major criterium for successful translocation in a given cell line is that CagA undergoes tyrosine phosphorylation $\left(\mathrm{CagA}^{\mathrm{PY}}\right)$ by host kinases of the Src and Abl family [70-73], which is commonly monitored in cell lysates or immunoprecipiates (IPs) using monoclonal phosphotyrosine-specific antibodies (Table 2). Interestingly, various studies noted significant cell type-specific differences in $\mathrm{CagA}^{\mathrm{PY}}$ levels during infection of human cell lines. In addition, injected $\mathrm{CagA}^{\mathrm{PY}}$ was reported for some cell types from mice and monkeys (Table 3), while selected other cell lines from humans, hamster or dog appeared to be resistant for detection of CagA $^{\mathrm{PY}}$ (Table 4). As controls, in vitro phosphorylation experiments of CagA with various cell lysates indicated that the kinases are active and strongly phosphorylated CagA [74]. Thus, the variation in $\mathrm{CagA}^{\mathrm{PY}}$ levels during infection evidently resulted from different levels of CagA translocation $[74,75]$. There are several scenarios that may explain the observed host cell specificity. One potential explanation is that specific host cell factors might be required to activate the T4SS. This activation could operate at the level of protein expression. For example, this is the case for the type-III secretion apparatus in Yersinia species [76]. However, CagA is one of the most abundant proteins in the proteome of $H$. pylori even in the absence of host cell contact [77] indicating that the translocation process is repressed, rather than a CagA expression effect. Indeed, despite its abundant presence, CagA is not secreted into the supernatant [78]. This represents a clever resource-saving strategy reminiscent to Shigella species, where effector proteins are stored in the bacterial cytoplasm before contacting host cells. In the latter case, translocation is triggered by a variety of factors, such as extracellular matrix proteins, bile salts or Congo red [79]. It was therefore proposed that the $H$. pylori T4SS might be similarly activated by specific factors exposed on the surface of specific target cells [61].

\section{The T4SS receptor hypothesis: role of host cell integrin}

Despite the above reports, it was assumed for many years that CagA can be randomly injected into gastric epithelial cells. However, this is obviously not the case because more recent studies showed that numerous host cell surface molecules are required for T4SS function, suggesting a sophisticated control mechanism through which $H$. pylori injects CagA [80]. The first identified 
Table 2 Reported phosphorylation/injection of CagA in human cell lines ${ }^{\mathrm{a}}$

\begin{tabular}{|c|c|c|c|c|c|}
\hline Cell line & Origin & H. pylori strains used & $\begin{array}{l}\text { Phospho- } \\
\text { CagA }^{b}\end{array}$ & $\begin{array}{l}\text { Applied } \\
\text { methods }\end{array}$ & References \\
\hline$\overline{A G S}$ & stomach & $\begin{array}{l}\text { G27, P1, P12, P210, GU301, GU303, GU304, GU305, GU306, GC401, GC402, 342, } \\
\text { ATCC43579, 87A300, NCTC11916, NCTC11637 }\end{array}$ & +++ & $\begin{array}{l}\text { IP, Anti-PY WB, } \\
C F, I F, 2-D E, M S\end{array}$ & {$[78,92-95]$} \\
\hline MKN-1 & stomach & $\mathrm{P} 12$ & + & IP, Anti-PY WB & {$[75]$} \\
\hline MKN-7 & stomach & P12 & + & IP, Anti-PY WB & {$[75]$} \\
\hline MKN-28 & stomach & $\mathrm{P} 1, \mathrm{P} 12$ & ++ & Anti-PY WB/IPA & [74] \\
\hline MKN-45 & stomach & $\mathrm{P} 1, \mathrm{P} 12$ & +++ & Anti-PY WB/IPA & [74] \\
\hline MKN-74 & stomach & $\mathrm{P} 12$ & + & IP, Anti-PY WB & {$[75]$} \\
\hline KATO-3 & stomach & $\mathrm{P} 1, \mathrm{P} 12$ & +++ & Anti-PY WB/IPA & {$[74]$} \\
\hline $23123 / 87$ & stomach & $\mathrm{P} 12$ & ++ & IP, Anti-PY WB & [75] \\
\hline $\mathrm{Hs}-746 \mathrm{~T}$ & stomach & $\mathrm{P} 12$ & ++ & IP, Anti-PY WB & {$[75]$} \\
\hline FU-97 & stomach & P12 & + & IP, Anti-PY WB & [75] \\
\hline NUGC-4 & stomach & P12 & + & IP, Anti-PY WB & [75] \\
\hline SNU-1 & stomach & P12 & + & IP, Anti-PY WB & [75] \\
\hline SNU-5 & stomach & $\mathrm{P} 12$ & ++ & IP, Anti-PY WB & {$[75]$} \\
\hline SNU-16 & stomach & P12 & + & IP, Anti-PY WB & {$[75]$} \\
\hline HeLa & cervix & $\mathrm{P} 1, \mathrm{P} 12$ & ++ & Anti-PY WB/IPA & {$[74,84]$} \\
\hline HT-29 & colon & $\mathrm{P} 1, \mathrm{P} 12$ & ++ & Anti-PY WB/IPA & [74] \\
\hline Hec1.b & endometrium & $\mathrm{P} 1, \mathrm{P} 12$ & + & Anti-PY WB/IPA & [74] \\
\hline 293T & kidney & $\mathrm{P} 1, \mathrm{P} 12$ & ++ & Anti-PY WB/IPA & [74] \\
\hline $\mathrm{HL}$ & lung & $\mathrm{P} 1, \mathrm{P} 12$ & ++ & Anti-PY WB/IPA & [74] \\
\hline HepG2 & liver & $\mathrm{P} 1, \mathrm{P} 12$ & ++ & Anti-PY WB/IPA & [74] \\
\hline MCF-7 & breast & $\mathrm{P} 12$ & +++ & Anti-PY WB & {$[72]$} \\
\hline THP1 & blood & P1, P12, ATCC43526 & +++ & Anti-PY WB & [96] \\
\hline U937 & blood & $\mathrm{P} 1, \mathrm{P} 12, \mathrm{G} 27$ & +++ & Anti-PY WB & [97] \\
\hline Josk-M & blood & $\mathrm{P} 1, \mathrm{P} 12, \mathrm{G} 27$ & +++ & Anti-PY WB & [97] \\
\hline $\begin{array}{l}\text { B cells, } \\
\text { primary }\end{array}$ & blood & $\mathrm{HM}-6, \mathrm{HM}-9$ & +++ & IP, Anti-PY WB & [98] \\
\hline $\mathrm{BJAB}$ & blood & HM-6, HM-9 & +++ & IP, Anti-PY WB & [98] \\
\hline
\end{tabular}

${ }^{a}$ Abbreviations: 2-DE (two-dimensional protein gel electrophoresis); anti-PY WB (Westernblotting of infected cell lysates using several pan-phospho-tyrosine antibodies); CF (cell fractionation); IF (localization by immunofluorescence); IP (immunoprecipitation); IPA (in vitro phosphorylation assays of CagA with cell lysates to ensure that active kinases are present in the cells of interest); MS (mass spectrometry of precipitated phospho-CagA).

b Intensity of CagA's tyrosine phosphorylation signals: +++ strong phosphorylation; ++ moderate phosphorylation; + weak phosphorylation.

host receptor for the T4SS was integrin $\beta 1$ [61]. Based on a series of experiments including the use of integrin $\beta 1$ knockout cell lines (GD25 and GD25 $\beta 1$ ), gene silencing RNAs, function-blocking antibodies and competition experiments with a well-known integrin $\beta 1$ bacterial adhesin (InvA from Yersinia), compelling evidence was provided that integrin $\beta 1$ plays a crucial role for injection of CagA during infection of several non-

Table 3 Reported phosphorylation/injection of CagA in cell lines other than human ${ }^{\text {a }}$

\begin{tabular}{|c|c|c|c|c|c|c|}
\hline Species & Cell line & Origin & H. pylori strains used & Phospho-CagA $^{\text {b }}$ & Applied methods & References \\
\hline Mouse & J774.A1 & blood & P1, P12, G27, ATCC43526 & +++ & IP, 2-DE, Anti-PY WB, MS & {$[96,97]$} \\
\hline Mouse & Fibroblast & embryo & $\mathrm{P} 12$ & + & Anti-PY WB, CF & [61] \\
\hline Mouse & SR 4987 & bone marrow & $\mathrm{P} 1, \mathrm{P} 12$ & + & Anti-PY WB/IPA & [74] \\
\hline Mouse & L929 & fibroblasts & $\mathrm{P} 1, \mathrm{P} 12$ & + & Anti-PY WB/IPA & [74] \\
\hline Monkey & Cos1 & kidney & P1, P12 & + & Anti-PY WB/IPA & [74] \\
\hline
\end{tabular}

${ }^{a}$ Abbreviations: 2-DE (two-dimensional protein gel electrophoresis); anti-PY WB (Westernblotting of infected cell lysates using several pan-phospho-tyrosine antibodies); IPA (in vitro phosphorylation assays of CagA with cell lysates to ensure that active kinases are present in the cells of interest); IF (localization by immunofluorescence), IP (immunoprecipitation); CF (cell fractionation); MS (mass spectrometry of precipitated CagA ${ }^{\mathrm{PY}}$ ).

${ }^{\mathrm{b}}$ Intensity of CagA's tyrosine phosphorylation signals: +++ strong phosphorylation; ++ moderate phosphorylation; + weak phosphorylation. 
Table 4 Cell lines with reported resistance for phosphorylation/injection of CagA a

\begin{tabular}{llllll}
\hline Cell line & Origin & Species & H. pylori strains used & Applied methods & References \\
\hline Hek293 & kidney & human & P1, P12, 26695, P310 & Anti-PY WB/SI & {$[99]$} \\
\hline GLC4 & Lung & human & P1, P12 & Anti-PY WB/IPA & {$[74]$} \\
\hline CHOK1 & Ovary & hamster & P1, P12 & Anti-PY WB/IPA & {$[74]$} \\
\hline MDCK & Kidney & dog & P1, P12 & Anti-PY WB/IPA & {$[74]$}
\end{tabular}

${ }^{a}$ Abbreviations: anti-PY WB (Westernblotting of infected cell lysates using several pan-phospho-tyrosine antibodies); IPA (in vitro phosphorylation assays of CagA with cell lysates to ensure that active kinases are present in the cells of interest); SI (synchronised infection assays: bacteria were centrifuged onto Hek293 cells to ensure proper contact of bacteria with these host cells).

polarised AGS and mouse cell lines [61]. In line with these observations, various structural T4SS proteins have been demonstrated to bind to integrin $\beta_{1}$ in vitro, including CagL, CagA, CagI and CagY (Table 1). However, while very little is known about interactions of CagA and CagI with integrin, CagL has been investigated intensively. Like the human extracellular matrix protein fibronectin, CagL carries a RGD-motif shown to be important for interaction with integrin $\beta_{1}$ on host cells, as well as downstream signaling to activate tyrosine kinases including EGFR, FAK and Src [81]. However, mutation of the RGD-motif in CagL revealed no reduction of injected $\mathrm{CagA}^{\mathrm{PY}}$ during infection in another study [82]. Another unsolved question is the structure of CagY with respect to which domain is exposed to the extracellular space. While the repeat domain in the middle of CagY on bacteria has been shown to be accessible to recognition by antibodies [64], in vitro binding studies and yeast-two hybrid screens revealed that the very carboxy-terminus interacted with integrin $\beta_{1}$ [82]. However, although it seems clear that each of the above factors exhibits an important functional role for injecting CagA, their interaction capabilities with integrin $\beta 1$ during infection are unknown, and need to be investigated in future studies.

\section{Role of phosphatidylserine and cholesterol for injection of CagA}

Another factor interacting with T4SS functions emerged from a recent study indicating that CagA binds directly to phosphatidylserine (PS) of the host cell and that this interaction is involved in CagA delivery into AGS cells based on saponin-fractionation experiments [83]. In vitro, the full-length protein binds to PS and this required a K-Xn-R-X-R motif present in the central region of CagA [83]. During H. pylori infection, the PSbinding protein annexinV and anti-PS antibodies both reduced CagA injection levels [83], suggesting that bacterial contact with PS is important for CagA delivery across the host membrane. Mutagenesis experiments showed that two arginine residues (R619 and R621) in the above motif are crucial for binding of purified CagA to PS and ensure membrane localization of transfected
CagA in polarized MDCK cells [83]. Murata-Kamiya and co-workers proposed that the reported CagL- $\beta 1$ integrin interaction may stabilize the CagA-PS interaction and may contribute to internalization of PS-bound CagA into host cells through activation of integrin signaling [83]. However, the injection mechanism of CagA into polarized MDCK cells is not completely clear because many other studies performed CagA transfection or biochemical fractionation experiments, but in most cases did not investigate phosphorylation of CagA [83-87]. The situation becomes even more puzzling because another group reported that MDCK cells are resistant to injection/phosphorylation of CagA upon infection [74]. Thus, the exact mechanism of CagA injection into polarized host cells requires further elucidation. Nevertheless, these findings point to the lipid bilayer in the host cell membrane as a second platform for T4SS-host cell interplay, rather then a "piercing"-like injection mechanism by the T4SS-pilus. Interestingly, recent findings from other groups indicated that cholesterol in lipid rafts, another component of the lipid bilayer, is also required for CagA translocation and proinflammatory signaling $[88,89]$. Taken together, these studies indicate that there are at least three host cell factors being involved in proper T4SS functions of $H$. pylori.

\section{Concluding remarks}

H. pylori is one of the most successful human pathogens. Studies of host-bacterial interactions using their fundamental adhesins and the virulence factors CagA and T4SS have provided us with many detailed insights in processes ultimately connected to $H$. pylori colonisation and pathogenesis. The current opinion implies a model in which the major adhesins BabA, SabA and others make the initial and sustained host cell contact important for bacterial colonisation. Once intimate contact is established, the T4SS further interacts with specific host cell surface molecules including integrins and PS to facilitate injection of CagA, probably in cholesterol-rich microdomains on host cells, the lipid rafts. The above discussed studies indicate that at least three known host factors are involved in CagA injection 
(integrin, PS and cholesterol). However, it also seems clear that some cell lines are resistant to injection of CagA indicating that none of the reported host factors alone can fascililtate the injection process. We therefore assume that the T4SS injection mechanism is much more complicated than originally proposed and probably requires even more host factors, probably acting cooperatively. It should also be noted that almost all of the functional T4SS studies have been made in vitro using cultured cell lines, which are indeed very helpful. However, we are aware of only one in vivo study, in which phosphorylated CagA was isolated from biopsies of atrophic gastritis and in noncancerous tissues from $H$. pylori-positive patients using immunoprecipitation and Western blotting approaches [90]. Thus, more studies are clearly necessary to investigate under which circumstances and how CagA is injected during infection in vivo. In particular, it remains to be investigated if CagA injection occurs at the apical, basolateral and/or other sites of the gastric epithelium. In addition, it has been convincingly shown that CagA can be very efficiently translocated into certain immune cells in vitro (Table 2). Thus, future studies are necessary to investigate the importance of these findings in vivo. Finally, the evolutionary advantage of the T4SS for $H$. pylori is also not yet clear and needs to be investigated more thoroughly. For example, recent studies indicated that injected CagA enables $H$. pylori to grow as microcolonies adhered to the host cell surface even in conditions that do not support growth of free-swimming bacteria [91]. Thus, it appears that the $H$. pylori T4SS will continue to be a fascinating and rewarding research topic in future studies.

\section{Acknowledgements \\ The work of S.B. is supported through grants from the Deutsche Forschungsgemeinschaft DFG grant (Ba1671/8-1), Science Foundation Ireland (UCD 09/IN.1/B2609) and from the National Institute of Diabetes and Digestive and Kidney Diseases (R56DK064371). The work of MC is supported through grants from Science foundation Ireland (UCD 08SRCB1393).}

\section{Author details}

'University College Dublin, School of Biomolecular and Biomedical Sciences, Science Center West, Belfield Campus, Dublin-4, Ireland. ${ }^{2}$ University College Dublin, School of Medicine and Medical Science, Health Science Center, Belfield Campus, Dublin-4, Ireland.

\section{Authors' contributions}

SB, MC and NT all contributed to the writing of this manuscript. All authors read and approved the final version of this manuscript.

\section{Competing statement}

The authors declare that they have no competing interests.

Received: 3 July 2011 Accepted: 1 November 2011 Published: 1 November 2011

\section{References}

1. Amieva MR, El-Omar EM: Host-bacterial interactions in Helicobacter pylori infection. Gastroenterology 2008, 134:306-323.
2. Atherton JC, Blaser MJ: Coadaptation of Helicobacter pylori and humans: ancient history, modern implications. J Clin Invest 2009, 119:2475-2487.

3. Polk DB, Peek RM Jr: Helicobacter pylori: gastric cancer and beyond. Nat Rev Cancer 2010, 10:403-414.

4. Backert S, Tegtmeyer N: The Versatility of the Helicobacter pylori Vacuolating Cytotoxin VacA in Signal Transduction and Molecular Crosstalk. Toxins 2010, 2:69-92.

5. Censini S, Lange C, Xiang Z, Crabtree JE, Ghiara P, Borodovsky M, Rappuoli R, Covacci A: cag, a pathogenicity island of Helicobacter pylori, encodes type I-specific and disease-associated virulence factors. Proc Natl Acad Sci USA 1996, 93:14648-14653.

6. Akopyants NS, Clifton SW, Kersulyte D, Crabtree JE, Youree BE, Reece CA, Bukanov NO, Drazek ES, Roe BA, Berg DE: Analyses of the cag pathogenicity island of Helicobacter pylori. Mol Microbiol 1998, 28:37-53.

7. Hatakeyama M: SagA of CagA in Helicobacter pylori pathogenesis. Curr Opin Microbiol 2008, 11:30-37.

8. Backert S, Tegtmeyer N, Selbach M: The versatility of Helicobacter pylori CagA effector protein functions: The master key hypothesis. Helicobacter 2010, 15:163-176.

9. Covacci A, Rappuoli R: Tyrosine-phosphorylated bacterial proteins: Trojan horses for the host cell. J Exp Med 2000, 191:587-592.

10. Tegtmeyer N, Wessler S, Backert S: Role of the cag-pathogenicity island encoded type IV secretion system in Helicobacter pylori pathogenesis. FEBS J 2011, 278:1190-1202

11. Viala J, Chaput C, Boneca IG, Cardona A, Girardin SE, Moran AP, Athman R, Mémet S, Huerre MR, Coyle AJ, DiStefano PS, Sansonetti PJ, Labigne A, Bertin J, Philpott DJ, Ferrero RL: Nod1 responds to peptidoglycan delivered by the Helicobacter pylori cag pathogenicity island. Nat Immunol 2004, 5:1166-1174.

12. Olofsson A, Vallström A, Petzold K, Tegtmeyer N, Schleucher J, Carlsson S, Haas R, Backert S, Wai SN, Gröbner G, Arnqvist A: Biochemical and functional characterization of Helicobacter pylori vesicles. Mol Microbiol 2010, 77:1539-1555.

13. Hoy B, Löwer M, Weydig C, Carra G, Tegtmeyer N, Geppert T, Schröder P, Sewald N, Backert S, Schneider G, Wessler S: Helicobacter pylori HtrA is a new secreted virulence factor that cleaves E-cadherin to disrupt intercellular adhesion. EMBO Rep 2010, 11:798-804.

14. Iver D, Arnqvist A, Ogren J, Frick IM, Kersulyte D, Incecik ET, Berg DE, Covacci A, Engstrand L, Borén T: Helicobacter pylori adhesin binding fucosylated histo-blood group antigens revealed by retagging. Science 1998, 279:373-377.

15. Aspholm-Hurtig M, Dailide G, Lahmann M, Kalia A, Ilver D, Roche N, Vikström S, Sjöström R, Lindén S, Bäckström A, Lundberg C, Arnqvist A, Mahdavi J, Nilsson UJ, Velapatiño B, Gilman RH, Gerhard M, Alarcon T, López-Brea M, Nakazawa T, Fox JG, Correa P, Dominguez-Bello MG, PerezPerez Gl, Blaser MJ, Normark S, Carlstedt I, Oscarson S, Teneberg S, Berg DE, Borén T: Functional adaptation of BabA, the $H$. pylori $\mathrm{ABO}$ blood group antigen binding adhesin. Science 2004, 305:519-522

16. Fujimoto S, Olaniyi Ojo O, Arnqvist A, Wu JY, Odenbreit $S$, Haas R, Graham DY, Yamaoka Y: Helicobacter pylori BabA expression, gastric mucosal injury, and clinical outcome. Clin Gastroenterol Hepatol 2007, 5:49-58.

17. Hennig EE, Allen JM, Cover TL: Multiple chromosomal loci for the babA gene in Helicobacter pylori. Infect Immun 2006, 74:3046-3051.

18. Azevedo M, Eriksson S, Mendes N, Serpa J, Figueiredo C, Resende LP, Ruvoën-Clouet N, Haas R, Borén T, Le Pendu J, David L: Infection by Helicobacter pylori expressing the BabA adhesin is influenced by the secretor phenotype. J Pathol 2008, 215:308-316.

19. Pride DT, Meinersmann RJ, Blaser MJ: Allelic Variation within Helicobacter pylori babA and babB. Infect Immun 2001, 69:1160-1171.

20. Bäckström A, Lundberg $C$, Kersulyte D, Berg DE, Borén T, Arnqvist A Metastability of Helicobacter pylori bab adhesin genes and dynamics in Lewis b antigen binding. Proc Natl Acad Sci USA 2004, 101:16923-16928.

21. Solnick JV, Hansen LM, Salama NR, Boonjakuakul JK, Syvanen M: Modification of Helicobacter pylori outer membrane protein expression during experimental infection of rhesus macaques. Proc Natl Acad Sci USA 2004, 101:2106-2111.

22. Styer CM, Hansen LM, Cooke CL, Gundersen AM, Choi SS, Berg DE, Benghezal M, Marshall BJ, Peek RM Jr, Borén T, Solnick JV: Expression of the BabA adhesin during experimental infection with Helicobacter pylori. Infect Immun 2010, 78:1593-1600. 
23. Ohno T, Vallström A, Rugge M, Ota H, Graham DY, Arnqvist A, Yamaoka Y: Effects of blood group antigen-binding adhesin expression during Helicobacter pylori infection of Mongolian gerbils. J Infect Dis 2011, 203:726-735

24. Ishijima N, Suzuki M, Ashida H, Ichikawa $Y$, Kanegae $Y$, Saito I, Borén T, Haas R, Sasakawa C, Mimuro H: BabA-mediated adherence is a potentiator of the Helicobacter pylori Type IV secretion system activity. J Biol Chem 2011, 15:25256-25264.

25. Gerhard M, Lehn N, Neumayer N, Borén T, Rad R, Schepp W, Miehlke S, Classen M, Prinz C: Clinical relevance of the Helicobacter pylori gene for blood-group antigen-binding adhesin. Proc Natl Acad Sci USA 1999, 26:12778-12783

26. Mahdavi J, Sondén B, Hurtig M, Olfat FO, Forsberg L, Roche N, Angstrom J, Larsson T, Teneberg S, Karlsson KA, Altraja S, Wadström T, Kersulyte D, Berg DE, Dubois A, Petersson C, Magnusson KE, Norberg T, Lindh F, Lundskog BB, Arnqvist A, Hammarström L, Borén T: Helicobacter pylori SabA adhesin in persistent infection and chronic inflammation. Science 2002, 297:573-578

27. Roche N, Angström J, Hurtig M, Larsson T, Borén T, Teneberg S: Helicobacter pylori and complex gangliosides. Infect Immun 2004, 72:1519-1529.

28. Marcos NT, Magalhães A, Ferreira B, Oliveira MJ, Carvalho AS, Mendes N, Gilmartin T, Head SR, Figueiredo C, David L, Santos-Silva F, Reis CA: Helicobacter pylori induces beta3GnT5 in human gastric cell lines, modulating expression of the SabA ligand sialyl-Lewis x. J Clin Invest 2008, 118:2325-2336.

29. Aspholm M, Olfat FO, Nordén J, Sondén B, Lundberg C, Sjöström R, Altraja S, Odenbreit S, Haas R, Wadström T, Engstrand L, Semino-Mora C, Liu H, Dubois A, Teneberg S, Arnqvist A, Borén T: SabA is the $H$. pylori hemagglutinin and is polymorphic in binding to sialylated glycans. PLOS Pathog 2006, 2:e110.

30. Walz A, Odenbreit S, Mahdavi J, Borén T, Ruhl S: Identification and characterization of binding properties of Helicobacter pylori by glycoconjugate arrays. Glycobiology 2005, 15:700-708.

31. Odenbreit S, Till M, Hofreuter D, Faller G, Haas R: Genetic and functional characterization of the alpAB gene locus essential for the adhesion of Helicobacter pylori to human gastric tissue. Mol Microbiol 1999, 31:1537-1548.

32. Odenbreit S, Swoboda K, Barwig I, Ruhl S, Borén T, Koletzko S, Haas R: Outer membrane protein expression profile in Helicobacter pylori clinical isolates. Infect Immun 2009, 77:3782-3790.

33. Senkovich OA, Yin J, Ekshyyan V, Conant C, Traylor J, Adegboyega P, McGee DJ, Rhoads RE, Slepenkov S, Testerman TL: Helicobacter pylori AlpA and AlpB bind host laminin and influence gastric inflammation in gerbils. Infect Immun 2011, 79:3106-3116.

34. Lu H, Wu JY, Beswick EJ, Ohno T, Odenbreit S, Haas R, Reyes VE, Kita M, Graham DY, Yamaoka Y: Functional and intracellular signaling differences associated with the Helicobacter pylori AlpAB adhesin from Western and East Asian strains. J Biol Chem 2007, 282:6242-6254.

35. Yamaoka Y, Kwon DH, Graham DY: A M(r) 34, 000 proinflammatory outer membrane protein (oipA) of Helicobacter pylori. Proc Natl Acad Sci USA 2000, 97:7533-7538.

36. Yamaoka Y, Ojo O, Fujimoto S, Odenbreit S, Haas R, Gutierrez O, ElZimaity HM, Reddy R, Arnqvist A, Graham DY: Helicobacter pylori outer membrane proteins and gastroduodenal disease. Gut 2006, 55:775-781.

37. Dossumbekova A, Prinz C, Mages J, Lang R, Kusters JG, Van Vliet AH, Reindl W, Backert S, Saur D, Schmid RM, Rad R: Helicobacter pylori HopH (OipA) and bacterial pathogenicity: genetic and functional genomic analysis of hopH gene polymorphisms. J Infect Dis 2006, 194:1346-1355.

38. Franco AT, Johnston E, Krishna U, Yamaoka Y, Israel DA, Nagy TA, Wroblewski LE, Piazuelo MB, Correa P, Peek RM Jr: Regulation of gastric carcinogenesis by Helicobacter pylori virulence factors. Cancer Res 2008, 68:379-\$87.

39. Peck B, Ortkamp M, Diehl KD, Hundt E, Knapp B: Conservation, localization and expression of HopZ, a protein involved in adhesion of Helicobacter pylori. Nucleic Acids Res 1999, 27:3325-3333.

40. de Jonge R, Durrani Z, Rijpkema SG, Kuipers EJ, van Vliet AH, Kusters JG: Role of the Helicobacter pylori outer-membrane proteins AlpA and AlpB in colonization of the guinea pig stomach. J Med Microbiol 2004, 53:375-379.
41. Giannakis M, Bäckhed HK, Chen SL, Faith JJ, Wu M, Guruge JL, Engstrand L, Gordon Jl: Response of gastric epithelial progenitors to Helicobacter pylori Isolates obtained from Swedish patients with chronic atrophic gastritis. J Biol Chem 2009, 284:30383-30394

42. Kennemann L, Didelot X, Aebischer T, Kuhn S, Drescher B, Droege M, Reinhardt R, Correa P, Meyer TF, Josenhans C, Falush D, Suerbaum S: Helicobacter pylori genome evolution during human infection. Proc Nat Acad Sci USA 2011, 108:5033-5038.

43. Covacci A, Telford JL, Del Giudice G, Parsonnet J, Rappuoli R: Helicobacter pylori virulence and genetic geography. Science 1999, 284:1328-1333.

44. Backert S, Meyer TF: Type IV secretion systems and their effectors in bacterial pathogenesis. Curr Opin Microbiol 2006, 9:207-217.

45. Fronzes R, Christie PJ, Waksman G: The structural biology of type IV secretion systems. Nat Rev Microbiol 2009, 7:703-714.

46. Backert S, Selbach M: Role of type IV secretion in Helicobacter pylori pathogenesis. Cell Microbiol 2008, 10:1573-1581.

47. Backert S, Fronzes R, Waksman G: VirB2 and VirB5 proteins: specialized adhesins in bacterial type-IV secretion systems? Trends Microbiol 2008 16:409-413.

48. Olbermann P, Josenhans C, Moodley $Y$, Uhr M, Stamer C, Vauterin M, Suerbaum S, Achtman M, Linz B: A global overview of the genetic and functional diversity in the Helicobacter pylori cag pathogenicity island. PLoS Genet 2010, 6:e1001069.

49. Fischer W, Püls J, Buhrdorf R, Gebert B, Odenbreit S, Haas R: Systematic mutagenesis of the Helicobacter pylori cag pathogenicity island: essential genes for CagA translocation in host cells and induction of interleukin-8. Mol Microbiol 2001, 42:1337-1348.

50. Kutter S, Buhrdorf R, Haas J, Schneider-Brachert W, Haas R, Fischer W: Protein subassemblies of the Helicobacter pylori Cag type IV secretion system revealed by localization and interaction studies. J Bacterio/ 2008 , 190:2161-71

51. Cendron L, Couturier M, Angelini A, Barison N, Stein M, Zanotti G: The Helicobacter pylori CagD (HP0545, Cag24) protein is essential for CagA translocation and maximal induction of interleukin-8 secretion. $J \mathrm{Mol} \mathrm{BiO} /$ 2009, 386:204-217.

52. Couturier MR, Tasca E, Montecucco C, Stein M: Interaction with CagF is required for translocation of CagA into the host via the Helicobacter pylori type IV secretion system. Infect Immun 2006, 74:273-281.

53. Pattis I, Weiss E, Laugks R, Haas R, Fischer W: The Helicobacter pylori CagF protein is a type IV secretion chaperone-like molecule that binds close to the C-terminal secretion signal of the CagA effector protein. Microbiology 2007, 153:2896-909.

54. Busler VJ, Torres VJ, McClain MS, Tirado O, Friedman DB, Cover TL: Proteinprotein interactions among Helicobacter pylori cag proteins. J Bacterio 2006, 188:4787-8400.

55. Chandran V, Fronzes R, Duquerroy S, Cronin N, Navaza J, Waksman G: Structure of the outer membrane complex of a type IV secretion system. Nature 2009, 462:1011-1015.

56. Yeo HJ, Savvides SN, Herr AB, Lanka E, Waksman G: Crystal structure of the hexameric traffic ATPase of the Helicobacter pylori type IV secretion system. Mol Cell 2000, 6:1461-1472.

57. Savvides SN, Yeo HJ, Beck MR, Blaesing F, Lurz R, Lanka E, Buhrdorf R, Fischer W, Haas R, Waksman G: VirB11 ATPases are dynamic hexameric assemblies: new insights into bacterial type IV secretion. EMBO J 2003, 22:1969-1980.

58. Hare $S$, Fischer W, Williams R, Terradot $L$, Bayliss R, Haas R, Waksman G: Identification, structure and mode of action of a new regulator of the Helicobacter pylori HP0525 ATPase. EMBO J 2007, 26:4926-4934.

59. Cendron L, Seydel A, Angelini A, Battistutta R, Zanotti G: Crystal structure of CagZ, a protein from the Helicobacter pylori pathogenicity island that encodes for a type IV secretion system. J Mol Biol 2004, 340:881-889.

60. Cendron L, Tasca E, Seraglio T, Seydel A, Angelini A, Battistutta R, Montecucco C, Zanotti G: The crystal structure of CagS from the Helicobacter pylori pathogenicity island. Proteins 2007, 69:440-443.

61. Kwok T, Zabler D, Urman S, Rohde M, Hartig R, Wessler S, Misselwitz R, Berger J, Sewald N, König W, Backert S: Helicobacter exploits integrin for type IV secretion and kinase activation. Nature 2007, 449:862-866.

62. Nesić D, Miller MC, Quinkert ZT, Stein M, Chait BT, Stebbins CE: Helicobacter pylori CagA inhibits PAR1-MARK family kinases by mimicking host substrates. Nat Struct Mol Biol 2010, 17:130-132. 
63. Tanaka J, Suzuki T, Mimuro H, Sasakawa C: Structural definition on the surface of Helicobacter pylori type IV secretion apparatus. Cell Microbiol 2003, 5:395-404

64. Rohde M, Püls J, Buhrdorf R, Fischer W, Haas R: A novel sheathed surface organelle of the Helicobacter pylori cag type IV secretion system. Mol Microbiol 2003, 49:219-234.

65. Andrzejewska J, Lee SK, Olbermann P, Lotzing N, Katzowitsch E, Linz B, Achtman M, Kado Cl, Suerbaum S, Josenhans C: Characterization of the pilin ortholog of the Helicobacter pylori type IV cag pathogenicity apparatus, a surface-associated protein expressed during infection. J Bacteriol 2006, 188:5865-1877.

66. Aras RA, Fischer W, Perez-Perez Gl, Crosatti M, Ando T, Haas R, Blaser MJ: Plasticity of repetitive DNA sequences within a bacterial (Type IV) secretion system component. J Exp Med 2003, 198:1349-1360.

67. Fischer W: Assembly and molecular mode of action of the Helicobacter pylori Cag type IV secretion apparatus. FEBS J 2011, 278:1203-1212.

68. Aly KA, Baron C: The VirB5 protein localizes to the T-pilus tips in Agrobacterium tumefaciens. Microbiology 2007, 153:3766-3775.

69. Delahay RM, Balkwill GD, Bunting KA, Edwards W, Atherton JC, Searle MS: The highly repetitive region of the Helicobacter pylori CagY protein comprises tandem arrays of an alpha-helical repeat module. J Mol Biol 2008, 377:956-971.

70. Selbach M, Moese S, Hauck CR, Meyer TF, Backert S: Src is the kinase of the Helicobacter pylori CagA protein in vitro and in vivo. $J$ Biol Chem 2002, 277:6775-6778.

71. Stein M, Bagnoli F, Halenbeck R, Rappuoli R, Fantl WJ, Covacci A: c-Src/Lyn kinases activate Helicobacter pylori CagA through tyrosine phosphorylation of the EPIYA motifs. Mol Microbiol 2002, 43:971-980.

72. Poppe M, Feller SM, Römer G, Wessler S: Phosphorylation of Helicobacter pylori CagA by c-Abl leads to cell motility. Oncogene 2007, 26:3462-3472.

73. Tammer I, Brandt S, Hartig R, König W, Backert S: Activation of Abl by Helicobacter pylori: a novel kinase for CagA and crucial mediator of host cell scattering. Gastroenterology 2007, 132:1309-1319.

74. Bauer B, Moese S, Bartfeld S, Meyer TF, Selbach M: Analysis of cell typespecific responses mediated by the type IV secretion system of Helicobacter pylori. Infect Immun 2005, 73:4643-4652.

75. Schneider S, Carra G, Sahin U, Hoy B, Rieder G, Wessler S: Complex Cellular Responses of Helicobacter pylori-Colonized Gastric Adenocarcinoma Cells. Infect Immun 2011, 79:2362-2371.

76. Pettersson J, Nordfelth R, Dubinina E, Bergman T, Gustafsson M, Magnusson KE, Wolf-Watz H: Modulation of virulence factor expression by pathogen target cell contact. Science 1996, 273:1231-1233

77. Backert S, Kwok T, Schmid M, Selbach M, Moese S, Peek RM Jr, König W Meyer TF, Jungblut PR: Subproteomes of soluble and structure-bound Helicobacter pylori proteins analyzed by two-dimensional gel electrophoresis and mass spectrometry. Proteomics 2005, 5:1331-1345.

78. Backert S, Ziska E, Brinkmann V, Zimny-Arndt U, Fauconnier A, Jungblut PR, Naumann M, Meyer TF: Translocation of the Helicobacter pylori CagA protein in gastric epithelial cells by a type IV secretion apparatus. Cell Microbiol 2000, 2:155-164.

79. Hueck CJ: Type III protein secretion systems in bacterial pathogens of animals and plants. Microbiol Mol Biol Rev 1998, 62:379-433.

80. Wessler S, Backert S: Molecular mechanisms of epithelial-barrier disruption by Helicobacter pylori. Trends Microbiol 2008, 16:397-405.

81. Tegtmeyer N, Hartig R, Delahay RM, Rohde M, Brandt S, Conradi J, Takahashi S, Smolka AJ, Sewald N, Backert S: A small fibronectin-mimicking protein from bacteria induces cell spreading and focal adhesion formation. J Biol Chem 2010, 285:23515-23526.

82. Jiménez-Soto LF, Kutter S, Sewald X, Ertl C, Weiss E, Kapp U, Rohde M, Pirch T, Jung K, Retta SF, Terradot L, Fischer W, Haas R: Helicobacter pylori type IV secretion apparatus exploits beta1 integrin in a novel RGDindependent manner. PLOS Pathog 2009, 5:e1000684.

83. Murata-Kamiya N, Kikuchi K, Hayashi T, Higashi H, Hatakeyama M: Helicobacter pylori exploits host membrane phosphatidylserine for delivery, localization, and pathophysiological action of the CagA oncoprotein. Cell Host Microbe 2010, 7:399-411.

84. Churin Y, Al-Ghoul L, Kepp O, Meyer TF, Birchmeier W, Naumann M Helicobacter pylori CagA protein targets the c-Met receptor and enhances the motogenic response. J Cell Biol 2003, 161:249-255.

85. Zeaiter Z, Cohen D, Müsch A, Bagnoli F, Covacci A, Stein M: Analysis of detergent-resistant membranes of Helicobacter pylori infected gastric adenocarcinoma cells reveals a role for MARK2/Par1b in CagA-mediated disruption of cellular polarity. Cell Microbiol 2008, 10:781-794.

86. Bagnoli F, Buti L, Tompkins L, Covacci A, Amieva MR: Helicobacter pylori CagA induces a transition from polarized to invasive phenotypes in MDCK cells. Proc Natl Acad Sci USA 2005, 102:16339-16344.

87. Amieva MR, Vogelmann R, Covacci A, Tompkins LS, Nelson WJ, Falkow S: Disruption of the epithelial apical-junctional complex by Helicobacter pylori CagA. Science 2003, 300:1430-1434.

88. Lai CH, Chang YC, Du SY, Wang HJ, Kuo CH, Fang SH, Fu HW, Lin HH, Chiang AS, Wang WC: Cholesterol depletion reduces Helicobacter pylori CagA translocation and CagA-induced responses in AGS cells. Infect Immun 2008, 76:3293-3303.

89. Hutton ML, Kaparakis-Liaskos M, Turner L, Cardona A, Kwok T, Ferrero RL: Helicobacter pylori exploits cholesterol-rich microdomains for induction of NF-kappaB-dependent responses and peptidoglycan delivery in epithelial cells. Infect Immun 2010, 78:4523-4531.

90. Yamazaki S, Yamakawa A, Ito Y, Ohtani M, Higashi H, Hatakeyama M, Azuma T: The CagA protein of Helicobacter pylori is translocated into epithelial cells and binds to SHP-2 in human gastric mucosa. J Infect Dis 2003, 187:334-337.

91. Tan S, Noto JM, Romero-Gallo J, Peek RM Jr, Amieva MR: Helicobacter pylori Perturbs Iron Trafficking in the Epithelium to Grow on the Cell Surface. PLOS Pathog 2011, 7:e1002050.

92. Segal ED, Cha J, Lo J, Falkow S, Tompkins LS: Altered states: involvement of phosphorylated CagA in the induction of host cellular growth changes by Helicobacter pylori. Proc Natl Acad Sci USA 1999, 96:14559-14564.

93. Odenbreit S, Püls J, Sedlmaier B, Gerland E, Fischer W, Haas R: Translocation of Helicobacter pylori CagA into gastric epithelial cells by type IV secretion. Science 2000, 287:1497-1500.

94. Stein M, Rappuoli R, Covacci A: Tyrosine phosphorylation of the Helicobacter pylori CagA antigen after cag-driven host cell translocation. Proc Natl Acad Sci USA 2000, 97:1263-1268.

95. Asahi M, Azuma T, Ito S, Ito $Y$, Suto H, Nagai $Y$, Tsubokawa M, Tohyama $Y$, Maeda S, Omata M, Suzuki T, Sasakawa C: Helicobacter pylori CagA protein can be tyrosine phosphorylated in gastric epithelial cells. J Exp Med 2000, 191:593-602.

96. Odenbreit S, Gebert B, Püls J, Fischer W, Haas R: Interaction of Helicobacter pylori with professional phagocytes: role of the cag pathogenicity island and translocation, phosphorylation and processing of CagA. Cell Microbiol 2001, 3:21-31.

97. Moese S, Selbach M, Zimny-Arndt U, Jungblut PR, Meyer TF, Backert S: Identification of a tyrosine-phosphorylated $35 \mathrm{kDa}$ carboxy-terminal fragment (p35CagA) of the Helicobacter pylori CagA protein in phagocytic cells: processing or breakage? Proteomics 2001, 1:618-629.

98. Lin WC, Tsai HF, Kuo SH, Wu MS, Lin CW, Hsu PI, Cheng AL, Hsu PN: Translocation of Helicobacter pylori CagA into Human B lymphocytes, the origin of mucosa-associated lymphoid tissue lymphoma. Cancer Res 2010, 70:5740-5748.

99. Kumar Pachathundikandi S, Brandt S, Madassery J, Backert S: Induction of TLR-2 and TLR-5 Expression by Helicobacter pylori Switches cagPAIDependent Signalling Leading to the Secretion of IL-8 and TNF-a. PLOS One 2011, 6:e19614.

doi:10.1186/1478-811X-9-28

Cite this article as: Backert et al:: Molecular mechanisms of gastric epithelial cell adhesion and injection of CagA by Helicobacter pylori. Cell Communication and Signaling 2011 9:28. 